PENELITIAN

\title{
Pengaruh Blok Paravertebral Injeksi Tunggal dan Multipel Terhadap Kadar Kortisol Plasma Pasien Tumor Payudara Yang Dilakukan Eksisi Biopsi
}

\author{
Dian Nugraha*, Himawan Sasongko**, Witjaksono ** \\ *Bagian Anestesiologi dan Terapi Intensif RS Harapan Keluarga Mataram, NTB \\ **Bagian Anestesiologi dan Terapi Intensif FK Undip/ RSUP Dr. Kariadi, Semarang
}

\section{ABSTRACT}

Background: Mostly, definitive treatment for breast surgery was done under general anaesthesia. But general anaesthesia was not able to inhibit pain transmission to the brain. It also have side effects such as postoperative nausea and vomiting. There are some regional anaesthesia techniques such as infiltration, epidural and thoracal paravertebral block. Paravertebral block technique is by injecting local anaeshesia to block somatic and symphatetic ipsilaterally above and below injection site. Surgical trauma can attenuate stress response (local and systemic), increase of cortisol level is one the endocrine systemic response.

Objective: To compare the difference effects between single injection and multiple injection thoracal paravertebral block in plasma cortisol and VAS in breast cancer patients undergoing biopsy excision.

Methods: Sample consists of 20 patients undergoing biopsy excision. Blood samples were taken at 8 in the morning before surgery and 8 tomorrow morning. VAS was checked at hour-0 (when the patient enter the recovery room) and hour-24. Patients divided into 2 groups, multiple (M) injection group and single (T) injection group. Normality of data was tested by Shapiro-Wilk the distribution is normal. Analytical analysis done with pre and post test group design.

Results: General characteristics on each group has normal distribution ( $p>0,05)$.

Plasma cortisol level after surgery in group $M(224,73 \pm 0,73)$ and $T(234,01 \pm 0,84)$ was lower than before surgery in group $M(256,55 \pm 0,91)$ and $T(258,34 \pm 0,91)$ but not significantly different $(p>0,05)$. VAS after surgey hour-0 in group $M(3,5 \pm 0,2)$ was lower than group $T(3,9 \pm 0,2)$ and significantly different $(p=0,02)$. VAS after surgey hour -24 in group $M(3,3 \pm 0,7)$ was lower than group $T(3,7 \pm 0,7)$ but not significantly different $(p=0,388)$.

Conclusion: VAS at hour-0 in group M was significantly lower than group T. There is no differences in plasma cortisol level and VAS hour-24 between multiple (M) injection group and single (T) injection group in patient undergoing biopsy excision.

Keywords: paravertebral block single injection, paravertebral block multiple injection, cortisol, VAS.

\section{ABSTRAK}

Latar Belakang Penelitian: Tindakan bedah definitif payudara banyak dilakukan dengan anestesi umum. Namun, dengan anestesi umum ada sebagian rangsang nyeri yang tidak 
terhambat ke otak dan medulla spinalis. Anestesi umum juga dikaitkan dengan insidensi mual dan muntah. Beberapa tehnik anestesi regional yang pernah disebutkan dalam literatur untuk operasi payudara antara lain dengan infiltrasi lokal, anestesi epidural torakal dan blok paravertebral torakal. Blok paravertebral torakal merupakan teknik injeksi lokal di samping vertebra torakal yang menyebabkan blokade saraf somatik dan simpatik ipsilateral pada dermatom torakal di atas dan di bawah lokasi injeksi. Trauma pembedahan menyebabkan respon inflamasi lokal dan respon metabolik endokrin sistemik. Respon sistemik setelah pembedahan meliputi peningkatan hormon katabolik seperti katekolamin, kortisol, renin, aldosteron, dan glukagon.

Tujuan: Membandingkan pengaruh antara blok paravertebral injeksi tunggal dan multipel terhadap kadar kortisol plasma dan VAS pasien yang dilakukan operasi eksisi biopsi.

Metode: Penelitian ini dilakukan pada 20 penderita tumor payudara yang menjalani operasi eksisi biopsi. Pengambilan sampel darah perifer untuk pemeriksaan kortisol pada jam 8 pagi sebelum operasi dan jam 8 pagi besoknya. Nilai VAS diperiksa pada jam ke-0 (saat pasien masuk ruang pemulihan), dan jam ke-24. Penderita dikelompokkan secara random menjadi 2 kelompok. Kelompok $M$ mendapat injeksi multipel dan kelompok $T$ mendapat injeksi tunggal. Dilakukan uji normalitas distribusi kadar kortisol darah dan VAS dengan menggunakan Shaphio-Wilk test. Apabila p>0,05 maka distribusinya disebut normal. Analisis statistik dilakukan untuk menguji perbedaan kelompok dengan pre dan post test group design, signifikan bila $p<0,05$.

Hasil: Data karakteristik sampel penelitian tiap kelompok terdistribusi normal( $p>0,05)$. Kadar kortisol plasma pasca operasi pada kelompok $M(224,73 \pm 0,73)$ dan $T(234,01$ $\pm 0,84)$ lebih rendah dibandingkan sebelum operasi pada kelompok $M(256,55 \pm 0,91)$ dan $T(258,34 \pm 0,91)$ tetapi tidak berbeda bermakna ( $p>0,05)$. VAS pasca operasi jam ke-0 pada kelompok $M(3,5 \pm 0,2)$ lebih rendah dibanding kelompok $T(3,9 \pm 0,2)$ dan berbeda bermakna $(p=0,02)$. VAS pasca operasi jam ke-24 pada kelompok $M(3,3 \pm 0,7)$ lebih rendah dibanding kelompok $T(3,7 \pm 0,7)$ tetapi tidak bermakna $(p=0,388)$.

Kesimpulan: VAS pasca operasi jam ke-0 kelompok $M$ lebih rendah secara signifikan dibanding kelompok T. Tidak didapatkan perbedaan bermakna pada kadar kortisol plasma dan VAS jam ke-24 pasca operasi antara injeksi multipel (M) dan injeksi tunggal (T) pada pasien yang menjalani eksisi biopsi.

Kata kunci: blok paravertebral injeksi tunggal, blok paravertebral injeksi multipel, kortisol, VAS.

\section{PENDAHULUAN}

Terapi bedah definitif payudara banyak dilakukan dengan anestesi umum. Namun, anestesi umum tidak menghambat transmisi nyeri ke otak dan medulla spinalis. Anestesi umum juga dikaitkan dengan 50\% insidensi mual dan muntah pada pasien bedah payudara. Komplikasi ini menyebabkan penderitaan 
bagi pasien, lama tinggal di unit perawatan pasca anestesi memanjang, rawat inap di RS lebih lama dan biaya rumah sakit meningkat. ${ }^{1,2}$

Beberapa teknik anestesi regional yang pernah disebutkan dalam kepustakaan untuk operasi payudara antara lain dengan infiltrasi lokal, anestesi epidural torakal dan blok paravertebral torakal. Blok paravertebral torakal merupakan teknik injeksi anestesi lokal di samping vertebra torakal yang menyebabkan blokade saraf somatik dan simpatik ipsilateral pada dermatom, di atas dan di bawah lokasi injeksi. ${ }^{3}$ Terdapat dua metode untuk blokade paravertebral torakal, yaitu injeksi multipel dan injeksi tunggal. Injeksi multipel merupakan metode yang lebih sering dilakukan. ${ }^{3,4}$

Trauma bedah menyebabkan respon inflamasi lokal dan respon metabolik endokrin sistemik. Respon lokal termasuk pelepasan sitokin, histamin, serotonin, prostaglandin, dan leukotrien. Respon sistemik setelah pembedahan meliputi peningkatan hormon katabolik seperti katekolamin, kortisol, renin, aldosteron, dan glukagon. ${ }^{5,6}$

Pada manusia, kortisol merupakan glukokortikoid primer. Kortisol memiliki efek kompleks pada metabolisme karbohidrat, lemak, dan protein. Kortisol mengurangi penggunaan glukosa perifer dengan efek anti-insulin dan juga menghambat pergerakan neutrofil dan monosit-makrofag ke daerah inflamasi. ${ }^{7,8}$

Anestesi regional dapat mengurangi respon stres bedah dengan menekan input aferen simpatik dan somatosensori. Inhibisi total terhadap respon stres memerlukan penggunaan obat anestesi lokal untuk memberikan blok total terhadap input simpatik dan somatosensori dari tempat trauma bedah. ${ }^{9}$

Visual analog scale (VAS) merupakan alat ukur yang digunakan untuk menilai karakteristik nyeri berdasarkan rentang nilai tertentu. Biasanya VAS menggunakan parameter berupa garis horisontal, dengan panjang $100 \mathrm{~mm}$ dengan interpretasi tertentu. Pasien kemudian diminta untuk menandai titik dimana titik tersebut menggambarkan persepsi nyeri pasien pada saat itu. Intepretasi VAS yaitu 0-4 mm: tidak nyeri, 5-44 mm: nyeri ringan, 4-74: nyeri sedang, 75-100: nyeri berat. ${ }^{10}$

Detterbeck dkk mengkaji 619 pasien dari 17 penelitian pada operasi torakotomi dengan epidural dan blok paravertebral. Blok paravertebral memiliki efek bebas nyeri yang paling efektif dengan efek samping yang lebih sedikit. ${ }^{11}$ Nikolajsen dkk memeriksa 79 pasien yang dilakukan blok paravertebral multipel sebelum dilakukan anestesi umum. Skala nyeri dan tingkat penggunaan fentanyl selama perawatan di PACU lebih rendah secara signifikan. ${ }^{12}$ Greengrass dkk menerapkan penggunaan blok paravertebral pada 25 pasien tumor payudara rawat jalan. Dari 25 pasien, 20 pasien tidak memerlukan tambahan analgesik, kejadian mual dan muntah 
minimal, serta semua pasien memiliki tingkat kepuasan tinggi. ${ }^{3}$ Rebecca dkk meneliti 461 kasus mastektomi dengan atau tanpa diseksi limfonodi aksila dengan anestesi blok paravertebral dibandingkan teknik anestesi lain. Penelitian tersebut menemukan bahwa analisis biaya, lama rawat inap dan kebutuhan obatnya lebih minimal pada kelompok blok paravertebral. ${ }^{13}$

Richardson dkk mengadakan studi prospektif acak antara anestesi epidural torakal dan paravertebral pada 100 pasien dewasa yang dilakukan torakotomi. VAS, fungsi paru dan efek samping lebih rendah secara signifikan pada kelompok paravertebral. Terjadi peningkatan kortisol plasma yang lebih tinggi pada kelompok epidural. ${ }^{14}$ Sandra dkk meneliti ritme kortisol diurnal sebagai prediktor dalam tingkat bertahan hidup kanker payudara. Pasien dengan ritme kortisol abnormal karena disregulasi dari kortisol secara signifikan memiliki tingkat survival lebih rendah. ${ }^{15}$ Hill dkk melakukan penelitian pada 80 pasien dewasa yang menjalani torakoskopi unilateral menggunakan teknik blok paravertebral injeksi multipel. Hasil penelitian mereka menunjukkan kebutuhan opioid lebih rendah, nilai VAS lebih kecil, serta kadar kortisol dan sitokin lebih rendah secara bermakna. ${ }^{16}$

Pusch dkk meneliti blok paravertebral injeksi tunggal dengan anestesi umum pada 44 pasien yang dilakukan operasi tumor payudara. Mereka menemukan bahwa VAS pasca operasi, insidensi mual muntah, kebutuhan obat analgetik serta kadar interleukin lebih rendah secara signifikan pada kelompok paravertebral. ${ }^{17}$ Kumar dkk meneliti efikasi dari blok paravertebral injeksi tunggal pada 46 pasien tumor payudara yang dilakukan operasi payudara serta komplikasi pasca operasi yang terjadi. Hasil penelitian ditemukan 93\% pasien tidak membutuhkan tambahan analgetik, kepuasan pasien tinggi serta kejadian mual muntah lebih rendah. ${ }^{18}$

Berdasarkan data di atas, akan diteliti perbedaan kadar kortisol darah dan VAS antara blok paravertebral teknik injeksi tunggal dan teknik injeksi multipel pada pasien tumor payudara yang menjalani operasi eksisi biopsi.

Tujuan dari penelitian ini adalah membandingkan pengaruh blok paravertebral torakal injeksi tunggal dan multiple terhadap VAS dan kadar kortisol plasma darah pasien tumor payudara yang menjalani operasi eksisi biopsi.

\section{METODE}

Jenis penelitian ini adalah pre and post test design, dilakukan selama 6 bulan pada pasien tumor payudara yang akan menjalani eksisi biopsi di Instalasi Bedah Sentral RSUP dr. Kariadi Semarang, dengan sampel sebanyak 20 orang.

Kriteria inklusi meliputi: perempuan, umur 15-60 tahun, penderita tumor payudara yang menjalani operasi eksisi biopsi. 
Tabel 1. Karakteristik penderita pada tiap kelomp ok dalam rerata \pm simpang baku, tidak berbeda bermakna.

\begin{tabular}{llccc}
\hline No & \multicolumn{1}{c}{ Variabel } & $\begin{array}{c}\text { Kelompok } \\
\text { Injeksi } \\
\text { Tunggal (T) } \\
(\mathbf{n = 1 0 )}\end{array}$ & $\begin{array}{c}\text { Kelompok Injeksi } \\
\text { Multipel (M) } \\
(\mathbf{n = 1 0 )}\end{array}$ & p \\
\hline 1. & Umur (Tahun) & $41,61 \pm 13,65$ & $44,12 \pm 10,35$ & 0,568 \\
2. & Berat badan (Kg) & $54,30 \pm 7,72$ & $53,95 \pm 7,91$ & 0,477 \\
3. & Tinggi badan (Cm) & $157,26 \pm 3,91$ & $157,78 \pm 3,27$ & 0,233 \\
4. & Lama Operasi (Menit) & $45,21 \pm 12,10$ & $49,91 \pm 11,17$ & 0,828 \\
\hline
\end{tabular}

Tab el 2. Nilai rerata dan simpang baku pada nilai kortisol plasma sebelum operasi dan postoperasi pasien dengan injeksi tunggal

\begin{tabular}{ccccc}
\hline \multirow{2}{*}{ No } & Variabel & \multicolumn{2}{c}{ Kelompok Injeksi Tunggal } & p \\
\cline { 3 - 4 } & & Sebelum $(\mathbf{n}=\mathbf{1 0})$ & Pasca $(\mathbf{n}=\mathbf{1 0})$ & \\
\hline $\mathbf{1}$ & Kortisol & $258,34 \pm 0,91$ & $234,01 \pm 0,84$ & 0,163 \\
\hline
\end{tabular}

Tabel 3. Nilai rerata dan simpang baku pada nilai kortisol plasma sebelum operasi dan postoperasi pasien dengan injeksi multipel

\begin{tabular}{ccccc}
\hline No & Variabel & \multicolumn{2}{c}{ Kelompok Injeksi Multipel } & p \\
\cline { 3 - 4 } & & Sebelum $(\mathbf{n}=\mathbf{1 0})$ & Pasca $(\mathbf{n}=\mathbf{1 0})$ & \\
\cline { 3 - 4 } & & & \\
\cline { 3 - 4 } $\mathbf{1}$ & Kortisol & $256,55 \pm 0,91$ & $224,73 \pm 0,73$ & 0,061 \\
\hline
\end{tabular}

Tabel 4. Nilai rerata dan simpang baku pada nilai kortisol plasma sebelum operasi antara injeksi multipel dan injeksi tunggal

\begin{tabular}{ccccc}
\hline No & Variabel & \multicolumn{2}{c}{ Kadar kortisol plasma seb elum operasi } & \multirow{2}{*}{$\mathbf{p}$} \\
\cline { 3 - 3 } & & Injeksi Tunggal & Injeksi Multipel & \\
\multirow{2}{*}{1} & Kortisol & $258,34 \pm 0,91$ & $256,55 \pm 0,91$ & 0,650 \\
& & & & \\
\hline
\end{tabular}


Pasien dibagi menjadi 2 kelompok; kelompok $\mathrm{T}$ sebanyak 10 orang diberi injeksi tunggal blok paravertebral dan kelompok M sebanyak 10 orang diberi injeksi multipel blok paravertebral. Injeksi tunggal dilakukan pada $2,5 \mathrm{~cm}$ lateral prosesus spinosus vertebra torakal 4. Injeksi multipel dilakukan di tiga titik, yaitu pada $2,5 \mathrm{~cm}$ lateral prosesus spinosus vertebra torakal 1,3 dan 5 .

Kriteria eksklusi meliputi diabetes mellitus, kontraindikasi untuk dilakukan blok paravertebral, obesitas, terapi hormonal, terapi dengan kortison, penggunaan steroid inhalasi.

Analisis menggunakan uji normalitas data dengan Shapiro Wilk test dan analisis deskriptif untuk menguji hipotesis dengan menggunakan Paired T-test dan Mann Whitney U test.

Etika penelitian dilakukan informed consent tertulis dengan penjelasan tujuan dan manfaat penelitian. Segala konsekuensi khususnya mengenai pembiayaan ditanggung oleh peneliti. Data pribadi penderita dijamin kerahasiaannya. Tidak terdapat konflik kepentingan dengan pihak manapun.

\section{HASIL}

Dari 20 pasien yang didapatkan, tidak terdapat perbedaan usia, berat badan, tinggi badan dan lama operasi sebagaimana tercantum pada Tabel 1 .

Tabel 2 menunjukkan bahwa pada kelompok injeksi tunggal nilai kortisol sebelum operasi dan pasca operasi tidak didapatkan perbedaan secara bermakna $(p=0,163)$.

Tabel 3 menunjukkan bahwa pada pada kelompok injeksi multipel nilai kortisol sebelum operasi dan pasca operasi tidak didapatkan perbedaan secara bermakna $(p=0,061)$.

Tabel 4 menunjukkan bahwa kadar kortisol sebelum operasi pada kelompok injeksi tunggal lebih besar dibandingkan kelopok injeksi multipel, namun tidak didapatkan perbedaan bermakna $(p=0,650)$.

Tabel 5 menunjukkan bahwa kadar kortisol pasca operasi pada kelompok injeksi tunggal lebih tinggi dibandingkan multipel namun tidak didapatkan perbedaan bermakna $(p=0,684)$.

Tabel 6 menunjukkan bahwa nilai VAS pada jam ke-24 lebih rendah dibandingkan pada jam ke-0, namun tidak didapatkan perbedaan bermakna $(\mathrm{p}=0,343)$.

Tabel 7 menunjukkan bahwa nilai dinyatakan sebagai rerata \pm simpang baku dengan kisaran. Nilai VAS pada jam ke-24 lebih rendah dibandingkan pada jam ke-0, namun tidak didapatkan perbedaan bermakna $(p=0,343)$.

Tabel 8 menunjukkan bahwa pada jam ke-0, nilai VAS pada kelompok injeksi multipel lebih rendah dibandingkan injeksi tunggal, dan berbeda bermakna secara statistik $(p=0,020)$. Sedangkan pada jam ke-24 nilai VAS pada 
Tabel 5. Nilai rerata dan simpang baku pada nilai kortisol plasma pasca operasi antara injeksi multipel dan injeksi tunggal

\begin{tabular}{ccccc}
\hline No & Variabel & Kadar kortisol plasma Pasca operasi & \multirow{2}{*}{$\mathbf{p}$} \\
\cline { 3 - 4 } & & & \\
\cline { 3 - 4 } & & Injeksi Tunggal & Injeksi Multipel & \\
& \multirow{2}{*}{1} & $234,01 \pm 0,84$ & $224,73 \pm 0,73$ & 0,684 \\
& & & \\
\hline
\end{tabular}

Tabel 6. Nilai rerata dan simpang baku pada nilai VAS antara jam-0 dan jam-24 pada kelompok injeksi tunggal

\begin{tabular}{ccccc}
\hline \multirow{2}{*}{ No } & Variabel & \multicolumn{2}{c}{ Nilai VAS } & p \\
\cline { 3 - 4 } & & Jamke-0 & Jamke-24 & \\
\multirow{nnyyn}{*}{$\mathbf{1}$} & VAS & $3,9 \pm 0,2$ & $3,7 \pm 0,7$ & 0,343 \\
\hline
\end{tabular}

Tabel 7. Nilai rerata dan simpang baku pada nilai VAS antara jam-0 dan jam-24 pada kelompok injeksimultipel

\begin{tabular}{llccc}
\hline \multirow{2}{*}{ No } & Variabel & \multicolumn{2}{c}{ Nilai VAS } & p \\
\cline { 3 - 4 } & & Jamke-0 & Jam ke-24 & \\
$\mathbf{n}$ & VAS & $3,5 \pm 0,2$ & $3,3 \pm 0,7$ & 0,321 \\
\hline
\end{tabular}

Tabel 8. Nilai rerata dan simpang baku pada nilai VAS jam-0 antara kelompok injeksi tunggal dan multipel dan jam-24 antara kelompok injeksi tunggal dan multipel

\begin{tabular}{lllll}
\hline No & Variabel & \multicolumn{2}{c}{ Nilai VAS } & p \\
& & Inj tunggal & Inj multipel \\
\hline $\mathbf{1}$ & & & & \\
& VAS jam ke-0 & $3,9 \pm 0,2$ & $3,5 \pm 0,2$ & 0,020 \\
$\mathbf{2}$ & VAS jam ke-24 & $3,7 \pm 0,7$ & $3,3 \pm 0,7$ & 0,388 \\
\hline
\end{tabular}


kelompok injeksi multipel lebih rendah dibandingkan injeksi tunggal, namun tidak didapatkan perbedaan bermakna $(\mathrm{p}=0,388)$.

\section{PEMBAHASAN}

Dari hasil penelitian didapatkan kadar konsentrasi kortisol plasma yang lebih rendah pasca operasi dibandingkan sebelum operasi pada kelompok injeksi tunggal, walaupun pada kelompok ini nilai kortisol sebelum operasi dan pasca operasi tidak terjadi perbedaan secara bermakna $(p=0,163)$. Begitu juga dengan kelompok injeksi multipel, dimana nilai kortisol pasca operasi lebih rendah dari nilai kortisol sebelum operasi tetapi tidak ditemukan perbedaan secara bermakna $(p=0,061)$.

Hasil tersebut sesuai dengan beberapa penelitian sebelumnya yaitu penelitian oleh Richardson dkk dengan studi prospektif acak antara anestesi epidural torakal dan paravertebral pada 100 pasien dewasa yang dilakukan torakotomi. Hasil penelitian mereka menunjukkan VAS, fungsi paru dan efek samping lebih rendah secara signifikan pada kelompok paravertebral. Sedangkan kortisol yang diperiksa sebagai parameter respon stress operasi tidak berbeda bermakna antara kedua kelompok, dengan nilai kortisol yang lebih rendah ditemukan pada kelompok blok paravertebral. Blok paravertebral memiliki efektivitas yang sama dengan blok epidural dan memiliki kelebihan dalam hal fungsi paru, respon stres neuroendokrin dan efek samping. ${ }^{14}$
Nilai VAS pada kelompok injeksi tunggal pada jam ke-24 lebih rendah dibandingkan pada jam ke-0, namun tidak didapatkan perbedaan bermakna $(p=0,343)$. Begitu juga nilai VAS pada kelompok injeksi multipel jam ke-24 lebih rendah dibandingkan pada jam ke0 , namun tidak didapatkan perbedaan bermakna $(p=0,321)$.

Kadar kortisol sebelum operasi pada kelompok injeksi tunggal lebih besar dibandingkan kelopok injeksi multipel, namun tidak didapatkan perbedaan bermakna $(p=0,650)$. Sedangkan kadar kortisol pasca operasi pada kelompok injeksi tunggal lebih tinggi dibandingkan multipel namun tidak didapatkan perbedaan bermakna $(p=0,684)$. Pada jam ke-0 dan jam ke-24 nilai VAS pada kelompok injeksi multipel lebih rendah dibandingkan injeksi tunggal dimana berbeda bermakna secara statistik $(\mathrm{p}=0,020)$ pada jam ke-0 dan tidak bermakna pada jam ke-24 ( $\mathrm{p}=0,388)$.

Keterbatasan penelitian ini adalah hasil penelitian yang tidak signifikan juga bisa disebabkan keterbatasan dalam jumlah sampel, durasi obat yang tidak bisa diprediksi serta waktu yang terbatas.

\section{SIMPULAN}

VAS pasca operasi jam ke-0 kelompok $\mathrm{M}$ lebih rendah secara signifikan dibanding kelompok T. Tidak didapatkan perbedaan bermakna pada kadar kortisol plasma dan VAS jam ke-24 pasca operasi antara injeksi multipel (M) dan injeksi tunggal $(\mathrm{T})$ pada pasien yang menjalani eksisi biopsi. 


\section{DAFTAR PUSTAKA}

1. Klein SM, Bergh A, Steele SM, Georgiade GS, Greengrass RA. Thoracic paravertebral block for breast surgery. Anesth Analg 2000;90:1402-5.

2. Coveney E, Weltz CR, Greengrass R, Iglehart JD, Leight GS, Steele SM, Lyerly HK. Use of paravertebral block anesthesia in the surgical management of breast cancer. Ann. Surg 1998;227(4):496-501.

3. Greengrass R, O'Brien F, Lyerly K, Hardman D, Gleason D, D'Ercole F, et al. Paravertebral block for breast cancer surgery. Can J Anaesth 1996;43(8):858-61.

4. Loader J, Ford P. Thoracic paravertebral block [clinical overview articles]. Update in anaesthesia. Available from: http:// www.anaesthesiologists.org

5. Durieux ME, Hollmann MW. Perioperative local anaesthetics and the inflammatory response administration [Proceeding book]. European society of anaesthesiologist. 2004 Jun 5. 107-10.

6. Kumar CM, Bellamy M, editor. Gastrointestinal and colorectal anesthesia. New York: Informa Healthcare USA. 2007.

7. Pendleton J. The role of cortisol in human physiology [internet homepage]. Updated 2009 Apr, Cited 2010 Nov. Available from: http://www.suite101.com/content/cortisola106593

8. American association for clinical chemistry. Cortisol [internet homepage]. Updated 2011 Mar, cited 2011 Apr. Available from: http:// www.labtestonline.org/understanding/ analytes/cortisol/tests.html

9. Raj P Prithvi. Textbook of regional anesthesia. Philadelphia: Churchill livingstone. 2002

10. Wemer M, Lowe K. A critical review of VAS in the measurement of clinical phenomena. Research in Nursing and Health 1990 : 227-236.

11.Davies RG, Myles PS, Graham JM. A comparison of the analgesic efficacy and sideeffects of paravertebral vs epidural blockade for thoracotomy - a systemic review and meta -analysis of randomized trials. Br J Anaesth 2006;96(4):418-26.

12.Moller JF, Nikolajsen L, Rodt SA, Ronning $\mathrm{H}$, Carlsson PS. Thoracic paravertebral block for breast cancer surgery: a randomized double-blind study. Anest Analg 2007;105 (6): $1848-51$.

13.Jankowski RM, Royce ME, Lee SJ, Kang H, Amdt C, Rosett RL, et al. Paravertebral block for breast surgery: a cost analysis [poster]. The university of new mexico. 2008 .

14.Richardson J, Sabanathan S, Jones J, Shah RD, Cheema, Mearns AJ. A prospective, randomized comparison of preoperative and continuous balanced epidural or paravertebral bupivacaine on post thoracotomy pain, pulmonary function and stress responses. Br J Anaesth 1999;83(3):387-92.

15. Sandra E, Robert M, David S. Diurnal cortisol rythim as a predictor of breast cancer survival. J Ntl Cancer Institute 2000;92:9941000.

16. Hill ES, Keller RA, Smith M, et al. Efficacy of single dose, multilevel paravertebral nerve for analgesia after thorascocopic procedures. American Society of Anesthesiologists. Anesthesiology 2006; 104:1047-53

17.Pusch F, Freitag H, Weinstabl C, Obwegeser R, Huber E, Wildling E. Single-injection paravertebral block compared to general anaesthesia in breast surgery. Acta Anaesthesiol Scand 1999;43(7):770-4.

18. Kumar A, Srivastava U, Saxena S, et al. Single injection paravertebral block for major breast surgery. J Anaesth Clin Pharmacol 2009; 25(3): 281-284 